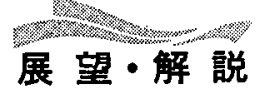

\title{
CAFVについて思うこと
}

小林 钽 雄**

\author{
Expectation for $\mathrm{CAFV}$
}

\section{Toshio KoBAyashi}

コンピュータはわれわれの生活の陆々にまで入 り込んでいる。病院に定期健康診断に行けばコン ピュータが健康状態を教えてくれるし，証券会社 では（不幸なことに私は未だ経験はないが）コン ピュータが株の買い方，売り方を教えてくれると いう。チェスではコンピュ一タの方が私上りはる かに強いし，囲基でもそるそるコンピュータに負 けそらである。しかしながら，これらのコンピュ 一タの能力はデータベースの集積とその分析であ り，決して創造的分野でないと思っていた。

ところが，最近ショッキングな記事を目にした。 作曲家でありコンピュータ学者でもある林二(リ ン・アル) 教授の「コンピュータ音楽の現在と末 来」といら話で，日本経済新聞の文化往来という コラムの中に載っていたものである。林教授は 20 年近くも前にイリノイ州立大学で世界最初のコン ピュータによる音楽会を開いたことで有名な力で あるが，彼は「真に創造的な作曲活動はコンピュ 一タだけができて人間にはできないものである」 と主張する。真比創造的な音楽は既存の音楽の様 式や要絜をすべて否定した所に存在し，人間の能 力は，たと立天才的な作曲家でも既存の音楽の様 式を全部知り，それを完全に否定与るとは不可 能である。高性能のコンピュータはそれができる ということらしい。睡存の様式をすべて否定する ことが創造性に結び付くか懝問であるが，芸術 の, しかも創造性の強く要求される分野でもコン ピュータの進出は急速に進んでいる。

科学技術の分野は既存の様式をすべて否定した 所に真の創造性が存在するといらよらな世界とは

*原稿受付 昭和63年 1 月12日

**東京大学生産技術研㚾所
買なる。幸いなことにわれわれの対象とするもの はもっと deterministic であり, コンピュータ の利用が受け入れられやすい分野である。

さて，最近の流れの可視化の分野に括けるコン ピュータの利用(CAFV : Computer Aided Flow Visualization) は, (1)数值計算による流れの生 成と表示, (2)間接測定結果からの流れの表示, 特 よび(3)可視化結果のディジタル画像処理に大別さ れよう。流れ解析の一方法としてのコンピュータ 利用は, CFD (Computational Fluid Dynamics）と呼ばれているが，高速コンピュータの発 達はこの CFD を応用数学の一分野から科学技術 開発の寒用的手段に䎐身させつつある。すなる ち，従来ほとんど不可能と考えられていた大規模 な乱流ンミュレーションを含めて複維な流れ現象 のCFDに上る解析の可能性が生じてきた。たと えば，膇大な時間と経費を費やしてきた航空機開 発の分野では，風洞実験の機能を CFD で代替し ようとするいわゆる「計算機風洞」の開発が現実な ものになりつつあるし，これに螌発されて航空工 学以外の分野でる哭験のある部分をCFDで代替, あるい悑補完しょらとする強い期待がある。これ らの計算機風洞を実現するにあたり必要とされる ものとして,流れ現象のモデリングに和ける知識, 数值計算法に拈ける知識などとともに画像表示に 関する知識やデータ輸送・インターフェースに係 わる技術などがあげられる。CFDによって得ら れた流れを現実の流れのよらに表示することがで きれば，それは流水を理解する上に有力な武器と なることはもちろん，計算された流れが妥当なも のであるか否かを診断する上でる有効なツールに 
なるであろう。昨秋, NASA Ames 研究所の数 值流体研究室を訪問する機会があった。そこでは 多くの CFD 研究者がスーパーコンピュータ CRAY-II を駆使し，大規模計算を試みていた が，画面上に現われる流れのアニメーションを見 て，計算結果の妥当性を議論していた。これらの 画像表示用のソフトウェアは数年間は, 米国外へ の移設は禁止されているとのことである。計算機 風洞は現状では幾つか樑題はもっているものの, それらの課題が克服されれば設計面での貢献とと もに実験では再現が困難なような現象，たとえば 乱流の微紐なメカニズム，核融合炣内のプラズマ 乱流の性状や半導体産業に和ける結晶成長過程な ぞの解明を期待してよいかも乙れない。

CAFV の第 2 の方向はピト一管, 熱線風速計, レーザ流速計，超音波流速計あるいは圧力計など による流速や圧力の間接測定結果を画像化するこ とである。これらの間接測定法はノウハウが十分 蓄積されて赫り，現在のところ最も信頼性の高い 流れ解析手法であろう。しかしながら多くの場 合，点の測定あるいは線の測定であり，流れ場の 全容を同時に测定することは難しい。たとえば乱 流境界層に扣けるバースト現象を熱線風速計を用 いて解明しよらとすれば，狭い空間に数多くの熱 線センサーを挿入しなければならず，本来の流れ 場を壞してしまらことになるら。定常流あるいは 周期的定常流の場合には 1 本あるいは 2 本以上の 熱線センサーのトラバースによって，流孔場全容 の各位相ごとの速度分邟を得ることは可能である が，非定常流の場合は不可能である。例外的に固 体壁面上の圧力分布の広域瞬時測定は可能であ る。NASA が開発した多点圧力計測装置を利用 し，わが国の建䚺会社（清水建設）が「スーパー 風洞実験システム」を開発し，風洞内に設置され た建物模型表面上の変動風厈を 512 か所で同時測 定し，それを等圧線に変換して画像表示した例が ある。アニメーション化することにより非定常流 れがわかり易く表現されており，新しいッールと して期待がもたれる。

間接測定法とコンピュータとの結び付きでもう 一つ忘れてはならないものはコンピュータトモグ
ラフィ(C T法)である。超音波やX線, $\gamma$ 線 ある いはレーザ光などを利用し流れの断層像を推定す ることができる。流れ場の三次元構造の把握は, 流 れ計測のターゲットの一つであり，CT法と画像 表示の組み合わせはその有望なッールであろう。

CAFV の第 3 の方は, 流れ場の測定手段とし て可視化技術を用い，その結果にディジタル画像 処理技術を適用することによって流机場の定量計 測を目指すことである。流れの可視化結果に適 用される画像処理技術は「2 値性画像の処理」と 「階調性画像の処理」K分類される。2 值性画像 の処理例としてはトレーサ粒子の運動軌跡を自動 的に追跡し速度べクトルを求める試みと噴流の輸 郭のように領域を判別するパターン認識的試みと に分けられる。いずれの処理に扣いてもソフトウ ェアとして既製のものが比較的用意され始めて拉 り，それらをらまく使い分けることが肝要であ る。この流れのディジタル画像解析は一般に, 流 れ場の全容を一時に観察することがでさるという 流れの可視化技術そのものの特徴を受け継いで いるものの，同時に测定精度が可視化技術に大き く依存することを忘れてはならない。しかしなが ら，境界層内のバースト現象の定量的把握にも適 用されて扣り, 微細現象の統計的処理などに威力 を発揮するよう期待される。さらに今後は流速と 珐力, 流速と温度などのように二つ以上の物理量 の同時定量測定により関心がもたれるものと予想 さ机る。

流れの可視化技術とコンピュータの保わり方を 分類し，それぞれの現状の概要を紹介した。CA FV に要求される課題はますます高度化し, 適用 事例も増大するものと思われる。しかしながら， いかにコンピュータが発達し流机に関するすべて の種類の情報が蓄積され画像として表示されるよ らになっても，流れの最終のイメージは依然とし てそれぞれの研究者の深い洞察が決定することに ならう。コンピュータは創造的な作曲家になるか もしれないが, 創造的な流体力学研究者にはなり 得ない。可視化技術もコンピュータも流れのイメ ージ構築のための補助手段として有効に機能させ たいものである。 